\title{
Exploring the Relationship between Human Resource Management Practices and Organizational Commitment: Empirical Evidence from the Banking Sector in China
}

\author{
*Faheem Ghazanfar ${ }^{1}$, Shuai Chuanmin'1, Muhammad Siddique ${ }^{2}$, Mohsin Bashir ${ }^{3}$ \\ ${ }^{1}$ China University of Geosciences, Wuhan, P. R. China \\ 2Institute of Management Sciences Hayatabad, Peshawar, Pakistan \\ ${ }^{3}$ Government College University, Faisalabad, Pakistan \\ *faheemghazanfar@yahoo.com
}

\begin{abstract}
The purpose of this paper is to measure the impact of human resource management practices individually and as a system on organizational commitment. Data were collected from 304 respondents from banking sector of China. A questionnaire survey for this purpose was conducted in different cities of China. Correlations and multiple regression statistics analysis were used to explore the relationship between the variables involved in the study. The findings of the study provide support for the variables (selection, training, performance appraisal, promotion, performance based rewards, information sharing, job security and human resource management system) and are confirmed by the results of the previous studies. The findings of the current study support the notion that the HR practices relates to organizational commitment, individually and as a system as well. These findings provide important avenues for the banking sector of China and for the debate regarding convergence of the human resource management practices regionally as well as internationally.
\end{abstract}

Key words: Human resource management practices; organizational commitment; China; Banking sector

\section{Introduction}

China, having seen a phenomenal growth in the last three decades of openness ideally sits right across the western economies, and has overpowered most of them in becoming the second largest economy of the world. Still in its transition phase, China faces numerous challenges to keep the progress going and one of the challenges is how the organizations in China tackle their human resources. In their study Helburn and Shearer (1984) pointed that "one of the most important but least understood elements of the economic system of the Peoples" Republic of China is that of human resource management'. After more than 30 years of China's reforms towards economic system and the management studies carried out in all these years on China specifically the review studies by (Li and Tsui 2002; Quer, Claver and Rienda 2007; Zhu, Thomson and De Cieri 2008) the question still remains there that how effective is human resource management in today's organizations of China. Developments in studying HR practices and their relationship to organizational performance are well known over the period. Extensive research with regard to the human resource practices and organizational performance relationship has established that they are related to organizational performance (Combs, Liu, Hall, \& Ketchen, 2006; Wright, Gardner, Moynihan, \& Allen, 2005; Ordonez de Pablos and Lytras, 2008; Chew and Basu, 2005; Khandekar and Sharma, 2005; Collins, 2007). Although, substantial literature is available which establishes an HR-performance relationship, however, it still lacks empirical research, which examines the mechanism having impact on the way this relationship works Wright and Gardner (2003). One way of looking into this mechanism is to focus on how human resource practices depict organizational commitment of the firm employees, a factor believed to influence their motivation and desire to put more effort so that the firm can ultimately improve its performance Wright and Kehoe (2008). Studies focusing on the HR practices, organizational commitment and performance relationship have focused on HR practices individually and as a HR system as well. Organizational commitment is believed to have an impact on different individual variables; e.g. competence, information sharing and rewards (Allen \& Meyer, 1990; Pare \& Tremblay, 2007). This focus on single HR practices has been challenged by authors like (MacDuffie, 1995) on theoretical and methodological grounds. To over come this problem HR system has been advocated to be the right choice, and has been supported by different studies, e.g. Takeuchi et al. (2009) in their study found that use of HR system had an association with individual employee job satisfaction and 
effective commitment. Keeping in view the above-mentioned background, the current study aims to provide in-depth analysis of the link between human resource practices and organizational commitment from employees' perspective. Moreover, the link between HR practices and organizational commitment will be looked into using both individual HR practices and HR system. As bulk of the research being carried out earlier focused on developed countries in the west, there is dearth of knowledge regarding human resource management practices and organizational commitment in countries besides west (Meyer \& Allen, 1997). However, the perception regarding the difference of culture between the western and eastern countries may lead to a different perspective regarding this discussion; this may result in organizational commitment being viewed differently by eastern country managers as compared to western country human resource managers. The current study, takes China having a different culture from the West (Hofstede, 2001), as an example, to address another aim of the study with a non-Western background. The data for the current study will in general come from banking sector of China. In order to do so, this article will proceed with the review of earlier work exploring the link between HR practices and organizational commitment. Further, the hypotheses development and methods used in this research will be explained. Finally, before concluding, the discussion and implications for future research in this area will be elaborated.

\section{HRM Practices and Organizational Commitment}

HRM practices and their influence on organizational commitment in an organization, in particular affective commitment, have been deliberated extensively in research Meyer and Allen (1997). HRM practices relating to selection procedures, training, performance appraisal, rewards, and job security are said to enhance Organizational commitment (Chang and Chen 2002; Meyer and Smith 2000; Whitener 2001; Wong et al. 2002). These findings are imperative that management can retain its valuable workers by keeping them committed to the organization. This will ultimately help organization to attract the quality worker from outside. The need to keep the work force committed, and to gain competitive edge through attractive quality workers has resulted in a surge in the research studies trying to look into HR practices and organizational commitment relationship. The findings of these research studies suggest that organizational commitment forecasts some significant variables; these include training, information sharing and rewards (Zaitouni et al. 2011; Pare \& Tremblay, 2007; Allen \& Meyer, 1990; Whitener, 2001). The existing researches also support the findings relating to organizational commitment and HR practices in a positive way (Mathieu \& Zajac, 1990; Paul and Anantharaman's 2004; Payne and Huffman 2005). Moreover, the existing research at system level also denotes the existence of a positive relationship among HRM system and organizational commitment Browning (2006). Social exchange theory gives a sound base to the positive relationship between HR practices and organizational commitment (Blau 1964; Witt, Kacmar, and Andrews 2001) which hypothesizes that employees and organizations go into exchange relationships, which inculcate the responsibility to give in return to the organization for the benefits it provides to them. The bulk of the aforementioned research was carried out in western countries, as this study is focused on China it is imperative to see how research has gone out in China with regard to the HR practices and organizational commitment. Research in the last decade or so has seen many studies being conducted to investigate the organizational commitment of employees working in China (Wong et al., 2001; Chen et al., 2002; Chiu, 2002; Cheng et al, 2003; Cheng and Stockdale, 2003; Wang, 2004; Chan et al., 2006; Yao and Wang 2006; Gamble and Huang 2008; Wang 2008). These studies focused on organizational type (Chiu, 2002; Wang, 2004), employee demographics Chen and Francesco (2000). However, there is a dearth of research being conducted on the effect of HR practices individually and as a system on organizational commitment of the employees in China.

Hypotheses Development: The Organizational commitment has been discussed and elaborated differently in the literature by different authors. However, the notable researches have interpreted organizational commitment in terms of worker's sustained and lasting relationship aiming to keep on working in the organization keeping the firm's goals and objective intact, and following with a spirited attempt to attain organizational goals (Steers, 1977; Mowday, Steers, \& Porter, 1979). Organizational commitment comprise of three types: affective is "defined as the employee's positive emotional attachment to the organization." continuance "the cost-benefit evaluation of whether to stay or leave", and normative "the feeling of being obliged to stay in the organization because of moral factors" Meyer \& Allen (1997). 
Selection and organizational commitment: In a competitive business environment of today, firms want to have a committed and productive workforce, and to attain this, use of HR practices is evermore important and progressive. This will help organizations to stay in contention and to manage the flow of employees' variety of conditions. This fact is also evident from the existing research where we do not find any similar studies that have used the same set of HR practices to study human resource management practices as a system Becker \& Gerhart (1996). Scholars have elaborated the human resource systems in three ways, which are its common dimensions (Delery 1998; Appelbaum et al. 2000). The first one relates to level of investment in an organization's HR practices addressing the knowledge, skills and abilities of the organizations' employees. The practices included in this dimension are recruiting, training, and selection. The second set of practices relates to enhancing motivation and the level of effort in an organization's employee, ingenuity, and performance. These include incentive pay plans, performance bonuses, and performance management systems. The third and final set of practices looks after the level of investment in HR practices in an organization to create an environment where employees feel and participate in decision making with regard to their work and about the outcomes. These three dimensions of HR practices as a system can be expected to influence organizational commitment, with each of these dimensions having its own effect. One of the effects of these practices relates to hiring and selection measures used by the organizations to ensure highly competent employees feel that they are at the right place and are part of the organization's family; this will lead the employees to be more committed to the organization Caldwell, et al. (1990). The above arguments allow us to hypothesize:

H1: Organizational selection practices are positively associated with organizational commitment.

Training and organizational commitment: Existing research on HR practices has identified training as an important practice having significant impact on organizational competitiveness, Schuler and MacMillan (1984). Research also suggests that the organizations investing considerably in training justify their investment by the contribution training makes to improve individual and organizational performance Bartel (2000). The investment in the training practices and the intended results sort by the organizations has lead researchers to look into it from different perspectives. In this regard, existing research has established a positive relationship between training and organizational performance (Collings et al. 2010; Lowry, Simon and Kimberley 2002). Besides, organizational performance and employee organizational commitment, substantial research has shown that training and development practices being employed by the organizations helps them to enhance employee skills and performance (Russell, Terborg and Powers 1985; Delaney and Huselid 1996).Organizations with a considerable effort and investment to train its employees intends to send a message to its employees that the development of its employees is an important factor to keep them committed to the organization McElroy (2001). The kind of message HRM practices sends might be of more influence than the practices themselves (Guzzo \& Noonan, 1994; Iles, Mabey \& Robertson, 1990). Recent times have seen training being addressed in the research literature looking into its relationship with organizational commitment (Owens 2006; Al-Emadi and Marquardt 2007). A lot of research exhibits that provision of training leads to improved level of employee organizational commitment (Ahmad and Bakar 2003; Al-Emadi and Marquardt 2007). The feeling that you are part of an unwritten psychological contract with the organization leaves employees to expect that they will be provided training opportunities understanding that in exchange they will display organizational commitment Bartlett (2001). Although there is a lot of research being carried out in Western countries investigating this (Klein 2001; Owens 2006), there is a dearth of research on this in China. The current study will shed some light of the role of training in the Chinese banking sector to enrich the existing literature.

H2: Employee training practices in an organization have a positive association with organizational commitment.

Performance appraisal and organizational commitment: Performance appraisal usually being an important HR practice is a well thought-out formal procedure, usually an annual interview, designed to provide a platform for managers and employees to discuss their past performance and their future needs which will help them to formulate action plans for the future Murphy and Cleveland (1995). With the developments in the management field performance appraisal has turned out not as a mere tool of recording and documenting employee's performance, but as a more strategic approach not only responsible for 
individual employee performance but also as a as a link between the head office and their sub offices and the individuals as well Fletcher (2004). In the existing literature Performance appraisal, in practice, has also been linked to some other facets of HRM systems, which are linked to training and performance-based compensation. In an organization performance appraisal system, if applied correctly, will enable to mark the performance levels and skills of the individuals and will help in identifying the shortcomings for whom training is recommended to be incorporated Locke, Latham and Smith (1990). This aspect brings performance appraisal practices to the fore as an important factor in an organization's HRM system. In his research, Fey et al (2000) hypothesize those HR practices of performance appraisal, which affects positively in enhancing employee's expertise and ability. The research supporting the idea, that the individual performance depends upon ability, motivation and opportunity, has grown substantially over the period of time Boxall and Purcell (2008). Social exchange theory states that the investing on employees in an organization on employees' will yield in employees becoming positive about their work behaviors Cropanzano and Mitchell (2005). This leads towards increased employee motivation level, which will instill a desire in them to use best of their effort and commitment to organization's advantage Kuvass and Dysvik (2009). Therefore, results of performance appraisal are expected to instill in employees a feeling of competence and accomplishment (Fey et al. 2009) and will result in more motivated and committed work force. However, the research carried so far has a different cultural background of west. This study being carried out in China will going to have a different perspective attached to it, because of the culture prevalent in the Chinese organizations differs from those of in the western countries. This discussion leads us to propose the following hypothesis

H3: There is a positive relationship between HR Performance appraisal practices and organizational commitment.

Promotion and organizational commitment: Another important aspect, which can also be linked to performance appraisal, is of promotion, which indicates that the organizations today emphasize much more on looking for the possibility of getting employees from with in the internal labor poll and internal career development. Guest (1997) states that availability of career development opportunities within an organization and commitment of employees are interrelated, because of the employees' view that there are career opportunities existing in organization. Highlighting internal career opportunities relating to promotion are likely to engender a sense of justice and fairness among employees, which will result in enhanced commitment level Fey et al. (2000). The focus on the provision of fair and equitable chances of getting promotion also helps firms not only to retain highly skilled employees but also to increase their commitment level. The above arguments lead us to have our next hypothesis:

H4: Promotion opportunities in an organization are positively linked with organizational commitment.

Performance based rewards and organizational commitment: Due to rapid changes taking place in the competitiveness among different organizations in the market and resultantly the change in the composition of the workforce, the emergence of work-life balance concept and, especially, the ever-rising costs associated with benefit schemes. The concepts of compensation and rewards being offered to employees are receiving increased attention from both employers and policy-makers. Existing research reflects a positive relationship between human resource practices relating to rewarding employees and organizational commitment. High reward subject to performance has been identified as one of the best practices and is integral to achieve organizational goals through improved levels of motivation and commitment Pfeffer (1998). Some of the studies have also contended that employees may some time doubt the way pay is allocated among the other employees as unfair practice (Trevor, Gerhart \& Boudreau, 1997), due to this reason in some of the studies, the relationship between pay and commitment was found insignificant (Trevor et al., 1997; Tekleab, Bartol\& Liu, 2005; Currall, Towler, Judge \& Kohn, 2005). In an organization offering attractive compensation packages employees view this as an indication that the employees' does matter for the organization and it looks after them. This will result in a strong affective commitment. This feeling will ultimately result in better continuance commitment, and attachment to the workplace, paving the way for a stronger normative commitment Meyer \& Allen (1997). Although there has been a surge in the volume of research been conducted in recent years focusing on the employee benefits and rewards field, the main focus has been on the relationship between rewards provision to the employees and their satisfaction at an individual level 
(Barber et al., 1992; Williams, 1995; Williams et al., 2002), some of the research has also looked into the relationship between satisfaction with compensation and further consequent outcomes related to human resource management (Behson, 2005; Blau et al., 2001; Casper and Harris, 2008; Dale-Olsen, 2006; Williams et al., 2002). Most of the research with regard to the rewards and compensation has been done in western countries, especially the USA and the UK, and rarely research studies have been conducted in Asian countries like China. Based on the above discussion we propose that:

H5: In an organization Performance, based rewards are positively associated with organizational commitment.

Information sharing and organizational commitment: Information sharing in an organization is more of a social issue and is considered integral part of the employees' organizational commitment Boer, van Baalen and Kumar (2002). These authors are of the view that information sharing between individuals is based on the notion of a good social relationship. In their research Li, Ardichvili, Maurer, Wentling and Stuedemann (2007) point out that information sharing is significant within groups as compared to general organizational community in which it is relatively weak. In another study the authors O'Neill and Adya (2007) argued that Chinese employees usually pay more attention to agreement and self-sacrifice, they are more willing to share information and knowledge with a group. The findings of this study give more credence to the research of Wasko and Faraj (2005) who were of the view that if information sharing is practiced effectively among employees on the bases of responsibility and teamwork, this will result in a sense of an obligation and reciprocity towards the organization as a whole. These findings will allow us to hypothesis that in organizations where information sharing is practiced employees will be more commitment towards their organization. Information sharing has been highlighted by Pfeffer (1998) as a key HRM practice. He was of the view that it resounds with an enhanced level of trust between employees and management, and provides a base for team working through information provision to employees, which enables them to put forward their suggestions for improvements in day-to-day business affairs. A lot of work done by the researchers identifies a positive relationship between information sharing and organizational commitment. Information sharing has been often used by the organizations as a key practice to improve upon the employee's commitment level to the organization. This discussion leads us to propose that:

H6: Information sharing practices are positively associated with organizational commitment

Job security and organizational commitment: Today an important issue being faced by the organizations is of job security and there has been a continuous and focused stream of research on this issue. In his work, Herzberg (1968) defines job security "as the extent to which an organization provides stable employment for employees". Meltz (1989) defines job security, as "an individual remains employed with the same organization with no diminution of seniority, pay, pension rights, etc." Job security is an important aspect and is very critical factor for swaying outcomes from employees relating to their work. Job security in this regard is an important factor to determine the physical and emotional sate of employees (Burke, 1991; Kuhnert and Palmer, 1991) and for employee turnover (Arnold and Feldman, 1982); for employee retention (Bhuian and Islam, 1996; Iverson and Roy, 1994); and for organizational commitment (Ashford et al., 1989; Iverson, 1996; Morris et al., 1993). Some other studies have also stated through their results that job security enhances employees' organizational commitment (Chang \& Chen, 2002; Meyer \& Smith, 2000). Chang (2005) is of the view that job security is a practice through which the organization conveys the message of commitment to the employees, and expects in return that the employees will respond through displaying their commitment to the organization. This reciprocal relationship supports the concept of social exchange theory (Blau, 1964). Based on the above we propose that:

H7: Job security is positively associated with organizational commitment.

HRM system and organizational commitment: HR practices if viewed from a strategic perspective suggest that HR practices should be taken as a combination of practices as a system rather than individual practices in looking for the relationship and interactions between managers and employees (MacDuffie 1995). Further, HRM systems consisting of individual HRM practices associated with each other displaying 'high internal fit' and with organizational strategy displaying 'high external fit' are believed to have greater influence on 
organizational performance than individual HRM practices (Bamberger and Meshoulam 2000; Bowen and Ostroff 2004). Empirical research using HRM system having internal consistency has a positive effect on firm performance (Bae and Lawler 2000; Chang and Chen 2002) and employee commitment (Chang and Chen 2002). The existing research at system level also shows a positive relationship between the HRM system and organizational commitment (Browning 2006). This leads us to propose our hypothesis between the relationship of HRM system and organizational commitment.

H8: HRM System is positively associated with the organizational commitment.

\section{The conceptual framework of the hypothesized relationship is outlined in Figure 1}

\section{Figure 1: Conceptual framework}

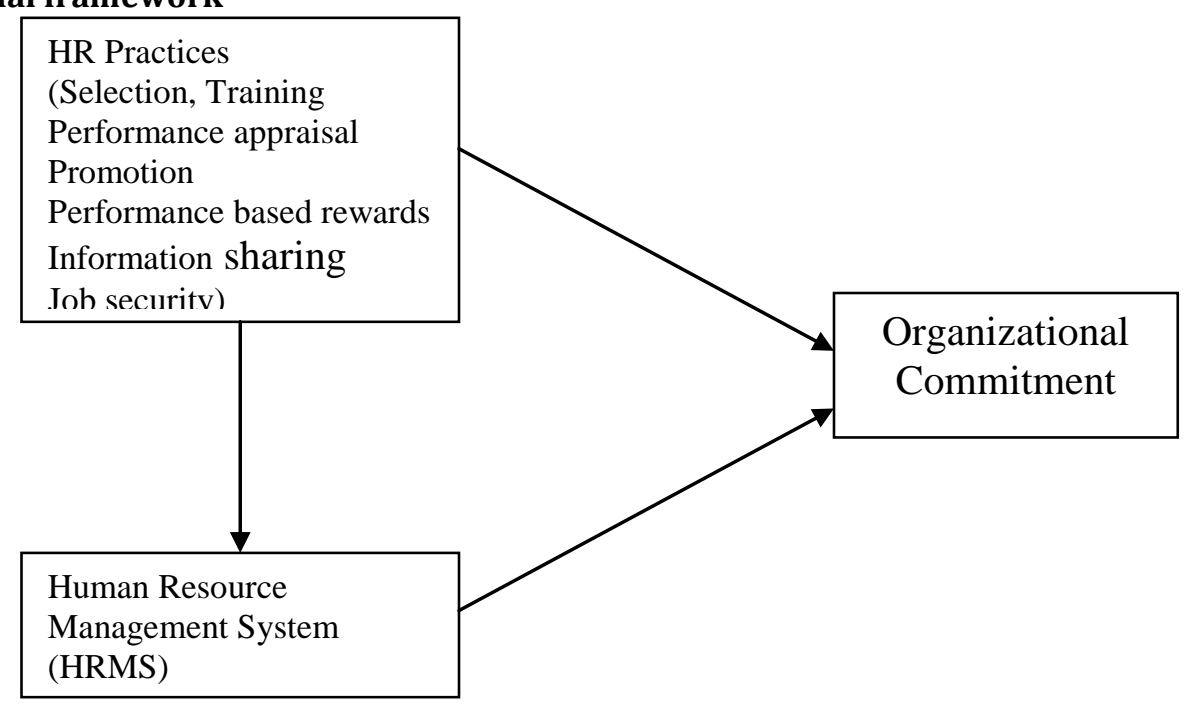

\section{Methodologies}

Having laid out a theoretical foundation of the proposed relationships, we will now discuss the methodologies adopted to test the proposed hypotheses.

Procedures: A questionnaire pertaining to HR practices and organizational commitment was originally developed in English language and then translated in Chinese language and translated back in English to have accurate translation for the present study. The translation was done by a native Chinese PhD student well versed with the terminology used in the field of human resource management. Later this questionnaire was discussed in the group to rectify any ambiguities. In total, 600 questionnaires pertaining to HR practices and organizational commitment were distributed to the employees working in different banks of China either in public or private sector. The said questionnaires were paper and pencil based which were administered personally as well as by snail mail. Participants were asked to voluntarily respond the questionnaires and were given ample time to complete it. The completed questionnaires were collected by the author either on the same day or the next day. The mailed questionnaires were sent back to the author by the managers of the concerned branches of the banks. In total, 315 employees' questionnaires were returned; of which 304 were usable, (11 questionnaires were discarded due to omitted responses). This resulted in 50.6 percent response rate.

Participants: The participating employees were of different cadres either full time or on contract bases working in various banks of China. The employees were only from banks, which were because, the current study's focus in on banking sector. The gender split between the respondents was 36.2 percent males and 63.8 percent females. With regard to the age groups the distribution was (e.g. 73 percent was less than 30 years , 17.8 percent between 30 to 39 years, 7.9 percent between 40 and 49 years, and only 1.3 percent who were more than 50 years old). These respondents consisted of 52.6 percent Clerical staff, 23 percent officer cadre, 23.7 percent middle management, and only 0.7 percent was from executive cadre. 
Measurement: The HR practices were measured with the scales of selection, training, performance appraisal, promotion, performance based rewards, information sharing, and job security. All the items pertaining to HR practices were scored with a five-point scale, ranging from (1) strongly disagree to (5) strongly agree. The HR practices were measured as follows: Selection was measured by four items using five-point Likert scale ranging from strongly disagree (1) to strongly agree (5). A sample item includes "Valid and standardized tests are used when required in the selection process". The Cronbach alpha for selection index was 0.88. Training was also measured by four items using five-point Likert scale ranging from strongly disagree (1) to strongly agree (5). The scale focused on weather the organization provides training opportunities to its employees and to what extent training is used for new hires and also for the promotability of the existing employees. A sample item includes "Extensive training programs are provided for individuals in this job". The Cronbach alpha for training was 0.78. Performance appraisal was composed of four items using the five-point Likert scale with the ranges of (1) strongly disagree to (5) strongly agree. Some of the items included were "Appraisal system in our organization is growth and development oriented". "The objectives of the appraisal system are clear to all employees. The Cronbach alpha for the performance appraisal was 0.85 . A five-point Likert scale was used to measure Promotion with the same range as used to measure the previous practices. The first two items asked the respondents about the opportunity of being promoted from within the organization and about the availability of potential positions. While the third item measured whether the firm plans for the career development of employees and fourth and the last one asked about the preference an employee gets whenever a vacancy exists. The Cronbach alpha for the promotion index was 0.82 . Performance-based rewards were measured by four items. Using a five-point, Likert scale ranging from (1) strongly disagrees to (5) strongly agree. The first two items ask the respondents whether the firm uses performance-based rewards and to what extent their reward systems are comparable to the market. The third item is about whether pay is tied to competence and ability, and the final item measures the extent to which compensation is directly linked to the performance of the employees. The Cronbach alpha for the performance-based rewards was 0.83. Information Sharing was measured by a scale composed of four items using five-point Likert scale (1) strongly disagree and (5) strongly agree. Some of the items were "employees in this job are allowed to make many decisions". "Superiors keep open communications with employees in this job". The Cronbach alpha for the information-sharing index was 0.88. Job Security index comprising of four items was measured using five-point Likert scale with the same scoring as used for the other HR practices in this study. Some of the sample items were "employees in this job can expect to stay in the organization for as long as they wish" and "If the bank were facing economic problems, employees in this job would be the last to get cut". The Cronbach alpha for the job security index was 0.80 . Organizational commitment was measured using a scale based on (Timothy et al. 2001). There were six items based on fivepoint Likert scale, scores ranges from (1) strongly disagree, and (5) strongly agree. Some of the sample items included were "I feel a strong sense of belonging to this organization". "I am proud to be working for this organization". The Cronbach alpha for this index was 0.85 .

\section{Results}

Table 1: Descriptive statistics and correlation coefficients of $H R$ practices with OC

\begin{tabular}{|c|c|c|c|c|c|c|c|c|}
\hline Variable name & Mean & S.D. & 1 & 2 & 3 & 4 & 5 & 6 \\
\hline Selection & 3.72 & 0.43 & $0.65^{* *}$ & & & & & \\
\hline Training & 3.81 & 0.34 & & $0.52^{* *}$ & & & & \\
\hline Performance appraisal & 3.67 & 0.42 & & & $0.62^{* *}$ & & & \\
\hline Promotion & 3.54 & 0.45 & & & & $0.59^{* *}$ & & \\
\hline Rewards & 3.63 & 0.46 & & & & & $0.63^{* *}$ & \\
\hline Information sharing & 3.26 & 0.48 & & & & & & $0.58^{* *}$ \\
\hline Job security & 3.21 & 0.49 & & & & & & $0.51^{*}$ \\
\hline Organizational commitment & 3.58 & 0.35 & & & & & & \\
\hline
\end{tabular}

Notes: ${ }^{* *} \mathrm{p}<0.01$ (two-tailed test). $\mathrm{N}=304$, OC (Organizational Commitment) 
Table 2: Regression results for HR practices on organizational commitment

\begin{tabular}{llcccccccc}
\hline Variable name & M1 & M2 & M3 & M4 & M5 & M6 & M7 & M8 & M9 \\
\hline $\begin{array}{l}\text { Independent variables } \\
\text { Selection }\end{array}$ & & & & & & & & & \\
Training & (H1) & $0.66^{* * *}$ & & & & & & & \\
Performance appraisal & (H3) & & $0.52^{* * *}$ & & & & & & \\
Promotion & (H4) & & & $0.62^{* * *}$ & & & & & \\
Rewards & (H5) & & & & $0.58^{* * *}$ & & & & \\
Information sharing & (H6) & & & & & $0.64^{* * *}$ & & & \\
Job security & (H7) & & & & & & $0.57^{* * *}$ & & \\
HRMS & (H8) & & & & & & & $0.50^{* * *}$ & \\
Control variables & & & & & & & & & $0.71^{* * *}$ \\
Gender & $-0.99^{*}$ & -0.05 & $-0.08^{*}$ & $-0.08^{*}$ & -0.02 & $-0.08^{* *}-0.06$ & -0.04 & -0.04 \\
Age Category & $-0.16^{*}$ & -0.10 & -0.09 & -0.11 & -0.07 & -0.07 & -0.04 & -0.00 & -0.02 \\
Marital Status & 0.67 & 0.07 & 0.08 & 0.08 & 0.07 & 0.05 & 0.02 & 0.08 & 0.07 \\
Experience in banking sector & 0.47 & $0.18^{* *}$ & 0.12 & $0.14^{*}$ & -0.07 & $-0.13^{*}$ & 0.04 & -0.06 & 0.09 \\
& & & & & & & & & \\
R-square & 0.03 & 0.44 & 0.29 & 0.41 & 0.36 & 0.42 & 0.34 & 0.28 & 0.51 \\
Adjusted R-square & 0.02 & 0.43 & 0.28 & 0.40 & 0.35 & 0.41 & 0.33 & 0.27 & 0.50 \\
\hline
\end{tabular}

Notes: $^{*} \mathrm{p}<0.1 ;{ }^{* *} \mathrm{p}<0.05 ;{ }^{* * *} \mathrm{p}<0.01$ (two-tailed test). $\mathrm{N}=304 ;$ M1-M9 (Model 1 to Model 9)

Table 3: Hypotheses results

\begin{tabular}{lll}
\hline Hypothesis & Variable name & Result \\
\hline H1 & Selection an d OC & Accepted \\
H2 & Training and OC & Accepted \\
H3 & Performance appraisal and OC & Accepted \\
H4 & Promotion and OC & Accepted \\
H5 & Rewards and OC & Accepted \\
H6 & Information Sharing and OC & Accepted \\
H7 & Job Security and OC & Accepted \\
H8 & HRMS and OC & Accepted \\
\hline
\end{tabular}

Table 1 shows the descriptive statistics and correlation coefficients of the current study between the independent variables with the organizational commitment as dependent variable. In the current study a series of regression analyses models were estimated in order to test the developed hypotheses. Nine models were tested for the dependent variable of organizational commitment. As the first step control variables were entered, (Model 1 in Table 2). In the control variables gender and age category had significant independent effect as control variables. The other two variables of marital status and experience in banking sector were insignificant with the organizational commitment. In the next step the individual effects of the hypothesized variables regarding human resource practices, together with the control variables were tested in Model 2 to 8 (Table 2). The first set of regression analyses was conducted with the organizational commitment as dependent variable. The results provide support for the hypotheses $\mathrm{H} 1$ as the coefficient was positive and significant $\mathrm{H} 1(0.66, \mathrm{p}<0.01)$ indicating the existence of a strong relationship between selection and organizational commitment providing support for the hypothesis one. Similarly for the other independent variables of the study the regression analyses were conducted and the correlation coefficient of the tests were positive and significant i.e. training $(0.52, \mathrm{p}<0.01)$; performance appraisal $(0.62, \mathrm{p}<0.01)$; promotion $(0.58$, $\mathrm{p}<0.01)$; rewards $(0.64, \mathrm{p}<0.01)$; information sharing $(0.57, \mathrm{p}<0.01)$; job security $(0.50 \mathrm{p}<0.01)$ indicating support for our other hypotheses. In the model 9, these HR practices were brought together as a human resource management system (HRMS) to check its effect on the organizational commitment. The result shows a positive and significant relationship between the HRMS and organizational commitment $(0.71, p<0.01)$. The summary of the tested hypotheses and their results is given in table 3 . These findings regarding the effects of the various HR practices were in accordance with the findings of the previous studies addressing the effects of these practices on organizational commitment (Chang and Chen, 2002; Bamberger and Meshoulam, 2000; 
Bowen and Ostroff, 2004; Meyer, Becker \& Vandenberghe, 2004; Pfeffer, 1998; Parker and Kyi, 2006; Casper and Harris, 2008; Kuvass and Dysvik, 2009; Fey et al. 2009).

Discussion: The primary purpose of the present study was to evaluate the effect of HR practices individually and as HR system in the banking sector of China. China, being the second largest economy of the world leaves a considerable influence on the things happening around the world, and in academic research as well, provides an ideal platform to look into the relationship between the HR practices and organizational commitment. We have tried to look into this relationship by developing 8 hypotheses regarding HR practices, HRMS and organizational commitment from a non-Western developing country's perspective. The results of hypotheses for the present study reveal that all the hypotheses were accepted (Table 2 and 3). As it can be noticed from the results mentioned in table 2, the organizational commitment of employees working in the banking sector of China depends on the HR practices mentioned in the current study individually and as a system as well. HR practices of selection, training, performance appraisal, promotion, performance based rewards, information sharing and job security are evidence that the organizations are ready to invest in human capital and provide their employees the opportunities to improve and develop their skills. If, the HR practices implemented by an organization instill a feeling of autonomy and competence in the employees this will result in better commitment level of the employees in the organization (Meyer et al. 2004). The results supported the hypothesis that the selection practices are positively associated with organizational commitment. This result is in accordance with the findings of (Caldwell, et al. 1990). The hypothesis regarding training practices was also found to be positively effecting the organizational commitment. These findings indicate that the organizations paying more attention to look after the training and development needs of their employees will yield better results with regard to the organizational commitment of the employees. These results are in line with the previous researches by (Meyer, Becker \& Vandenberghe, 2004; Emadi and Marquardt 2007). Current study's findings with regard to performance appraisal were also showing positive and significant effect on organizational commitment. The previous research by (Kuvass and Dysvik 2009) also gives support to the present findings and adds a developing country's perspective to the existing literature. Guest (1997) states that availability of career development opportunities within an organization and commitment of employees are interrelated, because of the employees' view that there are career opportunities existing in organization. This finding is seconded by the positive association shown by the results of the current study's hypothesis of promotion practices in the banking sector of China.

High rewards contingent on performance has been identified as one of the best practices and can be used as an incentive to boost employees' motivation and commitment to achieve organizational goals (Pfeffer 1998). In accordance with the previous research studies results the present study also supported the hypothesis that performance based rewards are positively associated with organizational commitment (Behson, 2005; Blau et al., 2001; Casper and Harris, 2008; Dale-Olsen, 2006; Zaitouni et al. 2011). Pfeffer (1998) highlighted information sharing as an important human resource practice. Many researchers (Meyer and Allen 1997; Guzley 2001; Zaitouni et al. 2011) have acknowledged that there exists a relationship between information sharing and organizational commitment. Organization uses information sharing practice to cement the employee's commitment level towards the organization. In their study the authors O'Neill and Adya (2007) argued that Chinese employees usually pay more attention to agreement and self-sacrifice, they are more willing to share information and knowledge with a group. These findings are especially important in view of the said previous findings and give credence to the present study, which supports the hypothesis of information sharing. Today an important issue being faced by the organizations is of job security and there has been a lot of attention being paid to this issue in the research studies. Results of the present study supported the hypothesis that the job security is positively associated with organizational commitment. These findings are supported by the earlier studies by (Iverson 1996; Morris et al. 1993; Chang \& Chen, 2002; Meyer \& Smith, 2000; Chang 2005). The existing research at system level has also found the relationship between the HRM system and organizational commitment (Browning 2006; Chang and Chen 2002). The findings of the current study also support this assertion that the HRMS is positively associated with the organizational commitment. 


\section{Conclusion and Implications}

China being a major player in the global economy and due to its openness in recent times has brought both benefits and challenges as well, especially with regard to the management of human resources. This challenge is becoming stern due to the lack of high skilled work force in china (e.g. Cooke, 2005, 2008; Ding et al., 2006; Gamble, 2000; Zhu and Warner, 2002). Moreover, due to high turnover of the highly skilled work force in China as compared to other Asian countries markets such as Malaysia and Singapore (Watson Wyatt, 2005). Accordingly, providing employees with a better environment and devising sound human resource policies and their implementation will be highly beneficial to attract and improve the commitment level of the existing work force in China and the findings of the present study will be of great help for the management of banks in China. The findings of the present are not with out limitations, which should be taken into consideration. Firstly, it would be ideal to explore managerial level employees' opinion about various HR practices in banking sector of China. This would provide further insights to the other side of the picture and will help organizations to be more effective in devising policies accordingly. Secondly, this study has focused only on one industry, the banking sector, which may not allow us to generalize the findings of the present study to the other areas. The sample size is of concern here as China is a big country and data from few cities cannot be generalized. Future research is needed to explore the relationship between HR practices and organizational commitment from multiple respondents across different industries. Research should also be carried out to look into some moderating variables, which might be having some effect on the relationship between HR practices and organizational commitment.

\section{References}

Ahmad, K. Z. \& Bakar, R. A. (2003). The Association between Training and Organizational Commitment among White Collar Workers in Malaysia. International Journal of Training and Development, 7(3), 166-185.

Al-Emadi, M. A. \& Marquardt, M. J. (2007). Relationship between Employees Beliefs Regarding Training Benefits and Organizational Commitment in a Petroleum Company in the State of Qatar. International Journal of Training and Development, 11, 1, 49-70.

Al-Emadi, M. A. S. \& Marquardt, M. J. (2007). Relationship between Employees' Beliefs Regarding Training Benefits and Employees Organizational Commitment in a Petroleum Company in the State of Qatar. International Journal of Training and Development, 11(1), 49-70.

Allen, N. J. \& Meyer, J. P. (1990). The measurement and antecedents of affective, continuance and normative commitment to the organization. Journal of Occupational Psychology, 63, 1-18.

Appelbaum, E., Bailey, T., Berg, P. \& Kallenberg, A. L. (2000). Manufacturing advantage. Why highperformance work systems pay off. Ithaca, NY: Cornell University Press.

Arnold, H. J. \& Feldman, D. C. (1982). A multivariate analysis of the determinants of job turnover. Journal of Applied Psychology, 67(3), 350-60.

Ashford, S. J., Lee, C. \& Bobko, P. (1989). Content, causes and consequences of job insecurity: a theory-based measure and substantive test. Academy of Management Journal, 32(4), 803-29.

Bae, J. \& Lawler, J. J. (2000). Organizational and HRM strategies in Korea: Impact on firm performance in an emerging economy. Academy of Management Journal, 43(3), 502-17.

Bamberger, P. \& Meshoulam, I. (2000). Human resource strategy: Formulation, implementation and impact. Thousand Oaks, CA: Sage.

Barber A., Dunham, R. \& Formisano, R. (1992). The impact of flexible benefits on employee satisfaction: A field study. Personnel Psychology, 45(1), 55-75.

Bartel, A. P. (2000). Measuring the Employer's Return on Investment in Training: Evidence from the Literature. Industrial Relations, 39(3), 502-524.

Bartlett, K. R. (2001). The Relationship between Training and Organizational Commitment: A Study in the Health Care Field. Human Resource Development Quarterly, 12(4), 335-352.

Becker, B. E. \& Gerhart, B. (1996). The impact of human resource management on organizational performance: Progress and prospects. Academy of Management Journal, 39, 779-801.

Behson, S. J. (2005). The relative contribution of formal and informal organizational work-family support. Journal of Vocational Behavior, 66(3), 487-500.

Bhuian, S. N. \& Islam, M. S. (1996). Continuance commitment and extrinsic job satisfaction among a novel multicultural expatriate work force. Mid-Atlantic Journal of Business, 32(1), 35-46. 
Blau, G., Merriman, K., Tatum, D. S. \& Rudmann, S. V. (2001). Antecedents and consequences of basic versus career enrichment benefit satisfaction. Journal of Organizational Behavior, 22(6), 669-688.

Blau, P. M. (1964). Exchange and power in social life. New York: Wiley

Blumberg, M. \& Pringle, C. D. (1982). The Missing Opportunity in Organizational Research: Some Implications of a Theory of Work Performance. Academy of Management Review, 7, 560-569.

Boer, N., van-Baalen, P. J. \& Kumar, K. (2002). The importance of sociality for understanding knowledge sharing processes in organizational contexts, ERIM Report Series Research in Management, Rotterdam Erasmus Research Institute of Management (ERIM).

Bowen, D. E. \& Ostroff, C. (2004). Understanding HRM-firm performance linkages: The role of the strength of the HRM system. Academy of Management Review, 29(2), 203-21.

Boxall, P. \& Purcell, J. (2008). Strategy and Human Resource Management (2 ${ }^{\text {nd }}$ ed.), Basingstoke: Palgrave Macmillan.

Browning, V. (2006). The relationship between HRM practices and service behavior in South African service organizations. International Journal of Human Resource Management, 17, 1321-38.

Burke, R. J. (1991). Job insecurity in stockbrokers: effects on satisfaction and health. Journal of Managerial Psychology, 6(5), 10-16.

Caldwell, D. F., Chatman, J. A. \& O'Reilly, C. A. (1990). Building Organizational Commitment: A Multifirm Study. Journal of Occupational Psychology, 63, 245-261.

Casper, W. J. \& Harris, C. M. (2008). Work-life benefits and organizational attachment: Self interest utility and signaling theory models. Journal of Vocational Behavior, 72(1), 95-109.

Chan, A. W., Feng, T. Q., Redman, T. \& Snape, E. (2006). Evaluating the Multi-Dimensional View of Employee Commitment: A Comparative UK-Chinese Study. International Journal of Human Resource Management, 17(11), 1873-1887.

Chang, E. (2005). Employee's overall perception of HRM effectiveness. Human Relations, 58(4), 523-544.

Chang, P. L. \& Chen, W. L. (2002). The effect of human resource management practices on firm performance: empirical evidence from Taiwan's high-tech firms. International Journal of Management, 19(4), 62231.

Chen, Z. X. \& Francesco, A. M. (2000). Employee Demography, Organizational Commitment, and Turnover Intentions in China: Do Cultural Differences Matter? Human Relations, 53(6), 869-887.

Chen, Z. X., Tsui, A. S. \& Farh, J. L. (2002). Loyalty to Supervisor vs. Organizational Commitment: Relationships to Employee Performance in China. Journal of Occupational and Organizational Psychology, 75, 339356.

Cheng, B. S., Jiang, D. Y. \& Riley, J. H. (2003). Organizational Commitment, Supervisory Commitment, and Employee Outcomes in the Chinese Context: Proximal Hypothesis or Global Hypothesis? Journal of Organizational Behavior, 24(3), 313-334.

Cheng, Y. \& Stockdale, M. S. (2003). The Validity of the Three-component Model of Organizational Commitment in a Chinese Context. Journal of Vocational Behavior, 62(3), 465-489.

Chew, K. H. \& Basu, S. (2005). The effects of culture and HRM practices on firm performance. Empirical evidence from Singapore. International Journal of Manpower, 26(6), 560-81.

Chiu, W. C. K. (2002). Do Types of Economic Ownership Matter in Getting Employees to Commit? An Exploratory Study in the People's Republic of China. International Journal of Human Resource Management, 13(6), 865-882.

Collings, D. G., Demirbag, M., Tatoglu, E. \& Mellahi, K. (2010). Strategic orientation, human resource management practices and organizational outcomes: evidence from Turkey. International Journal of Human Resource Management, 2(14), 2589-2613.

Collins, A. B. (2007). Human resources: a hidden advantage? International Journal of Contemporary Hospitality Management, 19(1), 78-84.

Combs, J. G., Ketchen, D. J. Jr., Hall, A. T. \& Liu, Y. (2006). Do high performance work practices matter? A Meta analysis of their effects on organizational performance. Personnel Psychology, 59, 501-528.

Cooke F. L. (2005). HRM, Work and Employment in China, Oxon: Routledge.

Cooke, F. L. (2008). Competition, Strategy and Management in China. New York: Palgrave Macmillan.

Cropanzano, R. \& Mitchell, M. S. (2005). Social Exchange Theory: An Interdisciplinary Review. Journal of Management, 31(6), 874-900.

Currall, S. C., Towler, A. J., Judge, T. A. \& Kohn, L. (2005). Pay satisfaction and organizational outcomes. Personnel Psychology, 58, 613-640. 
Dale-Olsen, H. (2006). Wage, fringe benefits and worker turnover. Labor Economics, 13(1), 87-105.

Davy, J. A., Kinicki, A. J. \& Scheck, C. L. (1991). Developing and testing a model of survivor responses to layoffs. Journal of Vocational Behavior, 38(3), 302-17.

Delaney, J. T. \& Huselid, M. (1996). The Impact of Human Resource Management Practices on Perceptions of Organizational Performance. Academy of Management Journal, 39(4), 949-969.

Delery, J. E. (1998). Issues of fit in strategic human resource management: Implications for research. Human Resource Management Review, 8, 289-309.

Ding, D., Akhtar, S. \& Ge, G. (2006). Organizational differences in managerial compensation and benefits in Chinese firms. International Journal of Human Resource Management, 17(4), 693-715.

Dyer, L. \& Holder, G. W. (1988). A strategic perspective of human resource management. In Human resource management: Evolving roles and responsibilities, ed. L. Dyer, 1.1-1.46. Washington DC: Bureau of National Affairs.

Dyer, L. \& Reeves, T. (1995). Human Resource Strategies and Firm Performance: What Do We Know, and Where Do We Need To Go? International Journal of Human Resource Management, 6, 657-667.

Fey, C. F., Bjo"rkman, I. \& Pavlovskaya, A. (2000). The Effect of Human Resource Management Practice on Firm Performance in Russia. International Journal of Human Resource Management, 11(1), 1-18.

Fey, C. F., Morgoulis-Jakoushev, S., Park, H. J. \& Bjo"rkman, I. (2009). Opening Up the Black Box of the Relationship Between HRM Practices and Firm Performance: A Comparison of USA,' Finland and Russia. Journal of International Business Studies, 40(4), 690-712.

Fletcher, C. (2004). Appraisal and Feedback: Making Performance Review Work, CIPD, London.

Gamble, J. (2000). Localizing management in foreign-invested enterprises in China: Practical, cultural and strategic perspectives. International Journal of Human Resource Management, 11(5), 883-903.

Gamble, J. \& Huang, Q. (2008). Organizational Commitment of Chinese Employees in Foreign- Invested Firms. International Journal of Human Resource Management, 19(5), 896-915.

Gardner, T. M., Moynihan, L. M., Park, H. J. \& Wright, P. M. (2001). Beginning to unlock the black box in the HR firm performance relationship: The impact of HR practices on employee attitudes and employee outcomes (CAHRS Working Paper \#01-12). Ithaca, NY: Cornell University, School of Industrial and Labor Relations.

Gavin, J. F. \& Axelrod, W. L. (1977). Managerial stress and strain in a mining organization. Journal of Vocational Behavior, 11(1), 66-74.

Gold, M. (2001). Breaking all the rules for recruitment and retention. Journal of Career Planning \& Employment, 61(3), 6-8.

Gomez-Mejia, L. R., Balkin, D. B. \& Cardy, R. L. (1995). Managing Human Resources. Englewood Cliffs, NJ: Prentice-Hall, Inc.

Guest, D. E. (1997). Human Resource Management and Performance: A Review and Research Agenda. International Journal of Human Resource Management, 8(3), 263276.

Guzley, R. M. (2001). Organizational climate and communication climate: Predictors of commitment to the organization. Management Communication Quarterly, 5(4), 379-402.

Guzzo, R. \& Noonan, K. (1994). Human resource practices as communications and the psychological contract. Human Resource Management, 33(3), 447-462.

Helburn, L. B. \& Shearer J. C. (1984). Human resources and industrial relations in China: a time of ferment. Industrial and Labor Relations Review, 38, 3-15.

Herzberg, F. (1968). Work and the Nature of Man, Granada, London.

Hofstede, G. (2001). Culture's consequences (2nd edn). Thousand Oaks, CA: Sage.

Iles, P., Mabey, C. \& Robertson, I. (1990). HRM Practices and employee commitment: Possibilities, pitfalls and paradoxes. British Journal of Management, 1(3), 147-157.

Iverson, R. D. (1996). Employee acceptance of organizational change: the role of organizational commitment. The International Journal of Human Resource Management, 7(1), 122-49.

Iverson, R. D. \& Roy, P. (1994). A causal model of behavioral commitment: evidence from a study of Australian blue-collar employees. Journal of Management, 20(1), 15-41.

Khandekar, A. \& Sharma, A. (2005). Managing human resource capabilities for sustainable competitive advantage. An empirical analysis from Indian global organizations. Education + Training, 47(8/9), 628-39.

Klein, H. J. (2001). Invited Reaction: The Relationship between Training and Organizational Commitment - A Study in the Health Care Field. Human Resource Development Quarterly, 12(4), 353-361. 
Koys, D. J. (1988). Human resource management and a culture of respect: Effects of employees' organizational commitment. Employee Rights and Responsibilities Journal, 1, 57-68.

Koys, D. J. (1991). Fairness, legal compliance, and organizational commitment. Employee Rights and Responsibilities Journal, 4(4), 283-291.

Kuhnert, K. W. \& Palmer, D. R. (1991). Job security, health and the intrinsic and extrinsic characteristics of work. Group \& organization studied, 16(2), 178-92.

Kuvass, B. \& Dysvik, A. (2009). Perceived Investment in Employee Development, Intrinsic Motivation and Work Performance. Human Resource Management Journal, 19, 217-236.

Li, J. T. \& Tsui, A. S. (2002). A citation analysis of management and organization research in the Chinese context: 1984 to 1999. Asia Pacific Journal of Management, 19, 87-107.

Li, W., Ardichvili, A., Maurer, M., Wentling, T. \& Stuedemann, R. (2007). Impact of Chinese culture values of knowledge sharing through online communities of practice. International Journal of Knowledge Management, 3(3), 46-59.

Lim, V. K. G. (1996). Job security and its outcomes: moderating effects of work based and non work-based social support. Human Relations, 49(2), 17194.

Lincoln, J. R. \& Kalleberg, A. L. (1996). Commitment, quite, and work organization in Japanese and U.S. Plants. Industrial and Labor Relations Review, 50, 39-59.

Locke, E. A., Latham, G. P. \& Smith, K. J. (1990). A Theory of Goal Setting and Task Performance, Englewood Cliffs, NJ: Prentice-Hall.

Lowry, D. S., Alan-Simon, A. \& Kimberley, N. (2002). Toward Improved Employment Relations Practices of Casual Employees in the New South Wales Registered Clubs Industry. Human Resource Development Quarterly, 13(1), 53-70.

MacDuffie, J. P. (1995). Human resource bundles and manufacturing performance. Industrial and Labor Relations Review, 48(2), 197-219.

Mathieu, J. E. \& Zajac, D. M. (1990). A review and meta-analysis of the antecedents, correlates, and consequences of organizational commitment. Psychological Bulletin, 108, 171-194.

McElroy, J. (2001). Managing workplace commitment by putting people first. Human Resource Management Review, 11(3), 327-335.

Meltz, N. M. (1989). Job security in Canada. Industrial Relations, 44(1), 149-60.

Meyer J. P., Becker T. E. \& Vandenberghe, C. (2004). Employee commitment and motivation: A-conceptual analysis and integrative model. Journal of Applied Psychology, 89, 991-1007.

Meyer, J. P. \& Allen, N. J. (1997). Commitment in the workplace: Theory, research, and application. Thousand Oaks, CA: Sage.

Meyer, J. P. \& Smith, C. A. (2000). HRM practices and organizational commitment: Test of a mediation model. Canadian Journal of Administrative Sciences, 17(4), 319331.

Meyer, J. P. \& Allen, N. J. (1997). Commitment in the workplace: Theory, research, and application. Thousand Oaks, CA: Sage.

Morris, T., Lydka, H. \& O'Creevy, M. F. (1993). Can commitment be managed? A longitudinal analysis of employee commitment and human resource policies. Human Resource Management Journal, 3(3), 2142.

Mowday, R. T., Steers, R. M. \& Porter, L. W. (1979). The measurement of organizational commitment. Journal of Vocational Behavior, 14, 224-247.

Mowday, R., Porter, L. \& Durbin, R. (1974). Unit performance, situational factors and employee attitudes in spatially separated work units. Organizational Behavior and Human Performance, 12, 231-248.

Murphy, K. R. \& Cleveland, J. N. (1995). Understanding Performance Appraisal: Social, Organizational, and Goal-Based Perspectives, Sage, and Thousand Oaks, CA.

O'Neill, B. S. \& Adya, M. (2007). Knowledge sharing and the psychological contract; managing knowledge workers across different stages of employment. Journal of Managerial Psychology, 22(4), 411-436.

Ordonez-de-Pablos, P. \& Lytras, M. D. (2008). Competencies and human resource management: implications for organizational competitive advantage. Journal of Knowledge Management, 12(6), 48-55.

Owens, P. L. (2006). One More Reason Not to Cut your Training Budget: The Relationship between Training and Organizational Outcomes. Public Personnel Management, 35(2), 163-172.

Pare, G. \& Tremblay, M. (2007). The influence of high-involvement human resources practices, procedural justice, organizational commitment, and citizenship behaviors on information technology professionals' turnover intentions. Group \& Organization Management, 32(3), 326-357. 
Parker, R. \& Kyi, L. (2006). Vertical information sharing in the budgeting process. Accounting. Organizations and Society, 31(1), 27-45.

Pascale, R. (1985). The paradox of 'corporate culture': Reconciling ourselves to socialization. California Management Review, 27(2), 26-40.

Paul, A. K. \& Anantharaman, R. N. (2004). Influence of HRM practices on organizational commitment: A study among software professionals in India. Human Resource Development Quarterly, 15(1), 77-88.

Payne, S. C. \& Huffman, A. H. (2005). A longitudinal examination of the influence of mentoring on organizational commitment and turnover. Academy of Management Journal, 48, 158-68.

Pfeffer, J. (1998). The Human Equation: Building Profits by Putting People First, Boston, MA: Harvard Business School Press.

Postames, T., Tanis, M. \& De-Wit, B. (2001). Communication and commitment in organizations: A social identity approach. Group Process and Intergroup Relations, 4(3), 227-246.

Quer, D., Claver, E. \& Rienda, L. (2007). The impact of country risk and cultural distance on entry mode choice: An integrated approach. Cross Cultural Management: An International Journal, 14(1), 74 - 87.

Rhoades, L., Eisenberg, R. \& Armeli, S. (2001). Affective commitment to the organization: the contribution of perceived organizational support. Journal of Applied Psychology, 86, 825-36.

Russell, J. S., Terborg, J. R. \& Powers, M. L. (1985). Organizational Performance and Organizational Level Training and Support. Personnel Psychology, 38(4), 849863.

Saks, A. M. (1995). Longitudinal Field Investigation of the Moderating and Mediating Effects of Self-Efficacy on the Relationship between Training and Newcomer Adjustment. Journal of Applied Psychology, 80, 211-225.

Schuler, R. S. \& MacMillan, I. C. (1984). Gaining Competitive Advantage through Human Resource Management Practices. Human Resource Management, 23(3), 241-255.

Smith, C. A. (1995). Human resource practices and policies as antecedents of organizational commitment. PhD dissertation, Western University.

Steers, R. (1977). Antecedents and outcomes of organizational commitment. Administrative Science Quarterly, 22(1), 46-56.

Takeuchi, R., Chen, G. \& Lepak, D. P. (2009). Through the looking glass of a social system: Cross level effects of high-performance work systems on employees' attitudes. Personnel Psychology, 62, 1-29.

Tannenbaum, S. I., Mathieu, J. E., Salas, E. \& Bowers, J. A. (1991). Meeting training expectations: The influence of training fulfillment on the development of commitment, self -efficacy, and motivation. Journal of Applied Psychology, 76, 75969.

Tekleab, A. G., Bartol, K. M. \& Liu, W. (2005). Is it paying levels or pay raises that matter to fairness and turnover? Journal of Organizational Behavior, 26, 899-921.

Thornhill, A., Lewis, P. \& Saunders, M. N. K. (1996). The role of employee communication in achieving commitment and quality in higher education. Quality Assurance in Education, 4(1).

Trevor, C. O., Gerhart, B. \& Boudreau, J. W. (1997). Voluntary turnover and job performance: Curvilinearity and the moderating influences of salary growth and promotions. Journal of Applied Psychology, 82(1), 44-61.

Trombetta, J. J. \& Rogers, D. P. (1988). Communication climate, job satisfaction, and organizational commitment: The effect of information adequacy, communication openness and decision participation. Management Communication Quarterly, 1(14), 494-514.

Wang, Y. (2004). Observations on the Organizational Commitment of Chinese Employees: Comparative Studies of State-Owned Enterprises and Foreign-Invested Enterprises. International Journal of Human Resource Management, 15(4), 649-669.

Wang, Y. (2008). Emotional Bonds with Supervisors and Co-Workers: Relationship to Organizational Commitment in China's Foreign-Invested Companies. International Journal of Human Resource Management, 19(5), 916-931.

Wasko, M. M. \& Faraj, S. (2005). Why should I share? Examining social capital and knowledge contribution in electronic network of practice. MIS Quarterly, 29(1), 35-57.

Watson, W. (2005). The Trend of China's Compensation and Benefits 2005. Beijing: Watson Wyatt Worldwide.

Whitener, E. M. (2001). Do high commitment human resource practices affect employee commitment? A cross-level analysis using hierarchical linear modeling. Journal of Management, 27(5), 515-535.

Williams, M. L. (1995). Antecedents of employee benefit level satisfaction: A test of a model. Journal of Management, 21(6), 1097-1128. 
Williams, M. L., Malos, S. B. \& Palmer, D. K. (2002). Benefit system and benefit level satisfaction: An expanded model of antecedents and consequences. Journal of Management, 28(2), 195-215.

Witt, L. A., Kacmar, K. M. \& Andrews, M. C. (2001). The interactive effects of procedural justice and exchange ideology on supervisor-rated commitment. Journal of Organizational Behavior, 22, 505-15.

Wong, C. S., Wong, Y. T., Hui, C. \& Law, K. S. (2001). The significant role of Chinese employee's organizational commitment: Implications for managing employees in Chinese societies. Journal of World Business, 36(3), 326-40.

Wong, Y. T., Ngo, H. Y. \& Wong, C. S. (2002). Affective organizational commitment of workers in Chinese joint ventures. Journal of Managerial Psychology, 17(7/8), 580-98.

Wright, P. M. \& Gardner, T. (2003). The human resource-firm performance relationship: Methodological and theoretical challenges. In The new workplace: A guide to the human impact of modern working practices, (eds) D. Holman, T. D. Wall, C. W. Clegg, P. Sparrow and A. Howard. John Wiley \& Sons, London.

Wright, P. M., Gardner, T. M., Moynihan, L. M. \& Allen, M. R. (2005). The relationship between HR practices and firm performance: Examining causal order. Personnel Psychology, 58, 409-446.

Wright, P. M. \& Kehoe, R. R. (2008). Human resource practices and organizational commitment: A deeper examination. Asia Pacific Journal of Human Resources, 46(6).

Yao, X. \& Wang, L. (2006). The Predictability of Normative Organizational Commitment for Turnover in Chinese Companies: A Cultural Perspective. International Journal of Human Resource Management, 17(6), $1058-1075$.

Zaitouni, M., Sawalha, N. \& Sharif, A. (2011). The impact of human resource management practices on organizational commitment in the banking sector in Kuwait. International Journal of Business and Management, 6(6).

Zhu, Y. \& Warner, M. (2002). Human Resource Management in China's 'Frontier? Special Economic Zone: A Study of Selected Enterprises on Hainan Island. International Journal of Employment Studies, 10(1), 75-104.

Zhu, J. C., Thomson, S. B. \& De-Cieri, H. L. (2008). A retrospective and prospective analysis of HRM research in Chinese firms: Implications and directions for future study. Human Resource Management, 47(1), 133-156. 